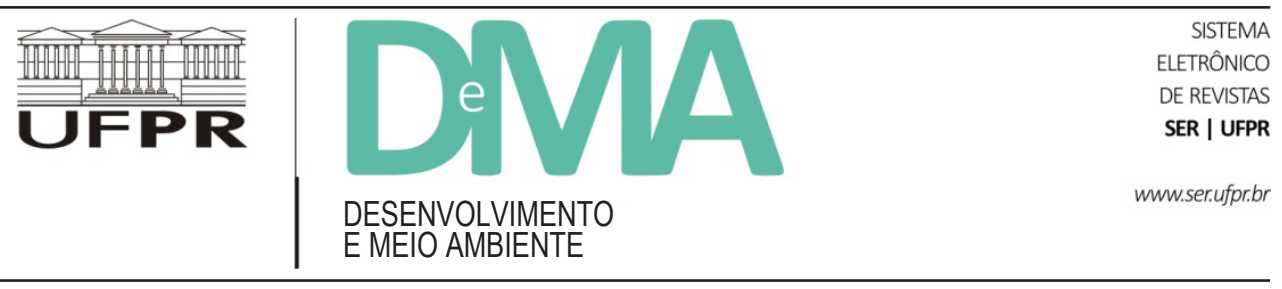

\title{
Prefácio ao primeiro número dos Cadernos de Desenvolvimento e Meio Ambiente, publicado em 1994
}

Em agosto de 1993 iniciava-se o Curso de Doutorado em Meio Ambiente e Desenvolvimento da Universidade Federal do Paraná, em Curitiba. Em março de 1994, esta mesma Universidade era contemplada com a atribuição de uma Cátedra da UNESCO para o Desenvolvimento sustentável - reconhecimento da originalidade de um processo que ela havia desencadeado com a criação deste curso interdisciplinar.

Estes dois fatos trazem indubitavelmente o testemunho de um sucesso que abre perspectivas encorajadoras para o futuro. Mas representam igualmente o coroamento de vários anos de trabalho realizado em múltiplas frentes:

- a de uma reflexão teórica referente às relações entre natureza e sociedades, entre meio ambiente e desenvolvimento, entre ciência e prática;

- de uma confrontação metodológica em torno do tema da interdisciplinaridade e de sua prática no campo da formação e da pesquisa;

- enfim, a de uma luta contra os estrangulamentos institucionais e sociais que manifestam-se assim que novos procedimentos e condutas passam a modificar os hábitos intelectuais e os poderes estabelecidos.

Este trabalho de amadurecimento compreendeu dois momentos importantes: o de um impulso inicial em abril de 1990, dado pela organização na UFPR de um Seminário Internacional sobre o enfoque interdisciplinar no campo do desenvolvimento; o de uma fase de síntese e de debates ampliados em julho de 1993, com a realização, também com o apoio da UFPR, de um Co- lóquio internacional sobre as Cátedras UNESCO para o desenvolvimento sustentável.

O trajeto entre estas duas etapas somente foi possível graças à colaboração exemplar entre a UFPR e as instituições francesas do ensino superior: a Universidade de Paris 7, a Universidade de Bordeaux 2 associada ao Centro Nacional da Pesquisa Científica, a Escola de Altos Estudos em Ciências Sociais, a Escola de Arquitetura de Paris-La Villette. Troca de experiências, discussão conjunta de ideias, confrontação de procedimentos, trata-se de um trabalho coletivo de longo prazo que permitiu a evolução de um projeto preliminar de Doutorado para um programa concreto de ensino e de pesquisa avalizado pelas autoridades científicas nacionais e internacionais. Esta mesma forma de cooperação permanece direcionando o Curso de Doutorado.

Este primeiro número dos Cadernos de Desenvolvimento e Meio Ambiente publicado pela UFPR é um testemunho desta colaboração e de algumas ideias que a motivaram. Podemos fazer aqui uma constatação bastante significativa: encontrar-se-ia dificilmente na França um projeto de formação e de pesquisa tão inovador como este que a UFPR promoveu. É no Brasil que os cientistas franceses têm encontrado eco às ideias por eles defendidas há muitos anos, assim como colaboradores que as têm compartilhado e posto em prática. Isto é clara expressão da vitalidade da comunidade científica deste país.

Claude Raynaut, Magda Zanoni 